University of Nebraska - Lincoln

DigitalCommons@University of Nebraska - Lincoln

2006

\title{
Sex Determination of Pohnpei Micronesian Kingfishers Using Morphological and Molecular Genetic Techniques
}

\author{
Dylan C. Kesler \\ U.S. Geological Survey, DylanKesler@picra.net \\ lara F. Lopes \\ Universidade Federal de Sao Carlos \\ Susan M. Haig \\ U.S. Geological Survey, Susan_Haig@usgs.gov
}

Follow this and additional works at: https://digitalcommons.unl.edu/usgsstaffpub

Kesler, Dylan C.; Lopes, lara F.; and Haig, Susan M., "Sex Determination of Pohnpei Micronesian Kingfishers Using Morphological and Molecular Genetic Techniques" (2006). USGS Staff -- Published Research. 680.

https://digitalcommons.unl.edu/usgsstaffpub/680

This Article is brought to you for free and open access by the US Geological Survey at DigitalCommons@University of Nebraska - Lincoln. It has been accepted for inclusion in USGS Staff -- Published Research by an authorized administrator of DigitalCommons@University of Nebraska - Lincoln. 


\title{
Sex determination of Pohnpei Micronesian Kingfishers using morphological and molecular genetic techniques
}

\author{
Dylan C. Kesler, ${ }^{1,2,4}$ Iara F. Lopes, ${ }^{1,3}$ and Susan M. Haig ${ }^{1}$ \\ ${ }^{1}$ USGS Forest and Rangeland Ecosystem Science Center, 3200 SW Jefferson Way, Corvallis, Oregon 97331, USA \\ ${ }^{2}$ Department of Fisheries and Wildlife, Oregon State University, Corvallis, Oregon 97331, USA \\ ${ }^{3}$ Departamento de Genética e Evolução, Universidade Federal de São Carlos, São Carlos, SP, Brazil
}

Received 1 December 2005; accepted 8 February 2006

\begin{abstract}
Conservation-oriented studies of Micronesian Kingfishers (Todiramphus cinnamominus) have been hindered by a lack of basic natural history information, despite the status of the Guam subspecies (T. $c$. cinnamominus) as one of the most endangered species in the world. We used tissue samples and morphometric measures from museum specimens and wild-captured Pohnpei Micronesian Kingfishers (T. c. reichenbachii) to develop methods for sex determination. We present a modified molecular protocol and a discriminant function that yields the probability that a particular individual is male or female. Our results revealed that females were significantly larger than males, and the discriminant function correctly predicted sex in $73 \%(30 / 41)$ of the individuals. The sex of $86 \%(18 / 21)$ of individuals was correctly assigned when a moderate reliability threshold was set. Sex determination using molecular genetic techniques was more reliable than methods based on morphology. Our results will facilitate recovery efforts for the critically endangered Guam Micronesian Kingfisher and provide a basis for sex determination in the 11 other endangered congeners in the Pacific Basin.
\end{abstract}

SINOPSIS. Determinación del sexo Todiramphus cinnamominus utilizando tecnicas morfologicas y genetica molecular

Estudios dirigidos a conservar a Todiramphus cinnamominus se han visto ausentes de conocimientos básicos sobre la historia natural del ave, aún tomándose en consideración que la subespecie de Guam es una de las formas más amenazadas con desaparecer. Utilizamos datos morfométricos de pieles en museo y muestras de tejido de la subespecie de Pohnpei (T. c. reichenbachii) para desarrollar un método útil para determinar el sexo de las aves. Presentamos un protocolo molecular modificado y una función de análisis discriminativo que ofrece una buena probabilidad para identificar los sexos. Nuestro estudio indica que las hembras son significativamente más grandes que los machos y el análisis estadístico predijo el sexo en el 73\% (30/41) de los individuos. El sexo del 86\% (18/21) de los individuos fue acertado cuando se preparó un umbral moderado de confiabilidad. El determinar el sexo utilizando genética molecular fue más confiable que usando morfometría. Nuestros resultados facilitarán los esfuerzos por recobrar a esta especie que esta criticamente amenazada y proveerá de una base sólida para determinar el sexo de 11 congéneres también amenazados que habitan en la Cuenca del Pacífico.

Key words: Halcyon cinnamomina, Micronesian Kingfisher, molecular sex determination, morphometrics, plumage, Todiramphus cinnamominus

Three subspecies of the Micronesian Kingfisher (Todiramphus cinnamominus) have been described from the islands of Guam (T. c. cinnamominus), Pohnpei (T. c. reichenbachii), and Palau (T. c. pelewensis). The Guam birds are extinct in the wild (Haig and Ballou 1995, Bahner et al. 1998, U.S. Fish and Wildlife Service 2004), drastic declines have been observed on Pohnpei (63\%; Buden 2000), and little is known about the status of the Palau kingfishers. Pohnpei Micronesian Kingfishers have been used as surrogates to address gaps in our knowledge

\footnotetext{
${ }^{4}$ Corresponding author. Email: DylanKesler@ picra.net
}

of this species and to facilitate recovery efforts for all three subspecies (e.g., Kesler and Haig 2004, U.S. Fish and Wildlife Service 2004). However, recent and ongoing investigations of distribution, resource use, behavior, and movements have been limited by a lack of natural history information and research tools. A means of determining sex is among the field research methods desperately needed for the Pohnpei and Palau subspecies of Micronesian Kingfisher that do not exhibit sexually dimorphic plumages (Pratt et al. 1987, Fry and Fry 1992).

Our goal was to facilitate field investigations and conservation-oriented research by providing methods for sex determination of Pohnpei Micronesian Kingfishers. We used tissue samples 
and morphological measures from museum specimens and wild-captured birds to test a new protocol for molecular genetic sexing based on polymerase chain reaction (PCR) of the chromo-helicase-DNA-binding (CHD) gene. Results obtained using molecular methods were then used in combination with multiple measures of museum specimens and wild-captured birds to derive a discriminate function for sex determination.

\section{METHODS}

Micronesian Kingfishers were studied at three locations on the island of Pohnpei, Federated States of Micronesia, that have been described elsewhere (Kesler 2002, Kesler and Haig 2005a,b). Birds were captured in mist nets during the following periods and months: February-July 1999, March and August 2000, September 2001, September 2002, January 2003, October and November 2003, and September 2004. Age was determined using breast, belly, and vent plumage coloration, with adults displaying white underparts and juveniles showing rufous (Pratt et al. 1987, Fry and Fry 1992). Yearlings and juveniles were also characterized by slight rufous coloration in the flanks, although they were primarily white throughout the belly and vent (D. Kesler, unpubl. data). For each captured bird, we measured tarsus length, exposed culmen, and wing chord. Each bird was also weighed using a 100-g spring scale (Pesola, Baar, Switzerland) and approximately $0.1 \mathrm{cc}$ of blood was drawn from the ulnar vein using a 27 -gauge needle. Blood was immediately placed in storage buffer $(100 \mathrm{mM}$ Tris- $\mathrm{HCl} \mathrm{pH} 8.0$, $100 \mathrm{mM}$ EDTA, $10 \mathrm{mM} \mathrm{NaCl}$, and $0.5 \%$ SDS) and frozen. Morphological measurements were also recorded from museum specimens at the American Museum of Natural History in New York, NY. D. Kesler recorded all morphological measures.

Molecular sex determination. We simplified a previously described protocol for sex determination (Jensen et al. 2003) by excluding the DNA extraction step and using different reagents. DNA was obtained from whole blood stored in buffer following Khatib and Gruenbaum (1996). Approximately $10 \mu \mathrm{l}$ of red blood cells were disrupted by boiling for $10 \mathrm{~min}$ in $12 \mu \mathrm{l}$ of $50 \mathrm{mM} \mathrm{NaOH}$ at $99^{\circ} \mathrm{C}$. The solution was neutralized using $22 \mu \mathrm{l}$ of Tris- $\mathrm{HCl} 1 \mathrm{M}$
$\mathrm{pH} 8.0$ and diluted by adding $1: 3(\mathrm{v} / \mathrm{v})$ proportion of sterile water. This suspension was boiled at $100^{\circ} \mathrm{C}$ for $10 \mathrm{~min}$ and used as the DNA source.

Fragments of genes CHD-Z and CHD-W located on the avian sex chromosomes were amplified using the primers P2 and P8 (Griffiths et al. 1998). The PCR amplification was performed in a final reaction volume of $10 \mu \mathrm{l}$ containing $1.5 \mu \mathrm{l}$ of DNA suspension, $1 \times$ PCR buffer (Promega Corporation, Madison, Wisconsin, USA), $3.5 \mathrm{mM} \mathrm{MgCl}_{2}, 25 \mathrm{mM}$ each dNTP, $25 \mu \mathrm{g} / \mathrm{ml}$ bovine serum albumin, $0.4 \mu \mathrm{M}$ each of primers $\mathrm{P} 2$ and $\mathrm{P} 8$, and 1 unit of Taq polymerase (Promega Corporation). The thermal cycling program was as follows: $3 \mathrm{~min}$ at $95^{\circ} \mathrm{C}$ (denaturation), 35 cycles of $30 \mathrm{sec}$ at $94^{\circ} \mathrm{C}, 30$ sec at $52^{\circ} \mathrm{C}, 45 \mathrm{sec}$ at $72^{\circ} \mathrm{C}$ (amplification), and $5 \mathrm{~min}$ at $72^{\circ} \mathrm{C}$ (final extension). Sex was identified through a $1.5 \%$ agarose gel electrophoresis visualized using ethidium bromide. PCR product produced a single band in males (derived from the $Z$ chromosome) and two bands in females ( $Z$ and $W$ fragments being amplified). Although previous results have revealed the reliability of sex determination through molecular techniques (Jodice et al. 2000), we repeated our analysis on six samples to ensure accuracy.

Morphometric analyses. Morphological analyses were conducted using museum specimens and wild-caught adult Pohnpei Microneian Kingfishers. Results of our genetic analyses were used to determine the sex of wild-caught individuals. The sexes of museum birds were taken from specimen tags. Differences in mean measures of weight, flattened wing cord, exposed culmen, and tarsus length (Baldwin et al. 1931) were evaluated using $t$-tests. Logistic regression was then used in a discriminate function analysis of morphological characteristics of adult Micronesian Kingfishers to evaluate sex differences in linear combinations of interval variables. Only data from wild-caught kingfishers without missing measurements were included. A linear combination of morphological measures was fitted to sex using binomial logistic regression. Once developed, the model equation was tested on all sampled kingfishers. All analyses were conducted using the Statistical Analysis System (SAS Institute 1999). Unless otherwise noted, metrics are reported as mean $\pm 1 \mathrm{SD}$, and differences were considered statistically significant at alpha $<0.05$. 


\section{RESULTS}

Blood samples from Pohnpei Micronesian Kingfishers $(N=66)$ analyzed with molecular methods showed the expected pattern of two bands in females and one band in males. The size and base pair (bp) difference between the two amplified CHD fragments were similar to those reported for Guam Micronesian Kingfishers ( $Z$ band $=350 \mathrm{bp}$ and $\mathrm{W}$ band $=400 \mathrm{bp}$; Jensen et al. 2003). We did not observe unspecific band amplification. To test the reliability of the molecular method, samples collected from the same individuals on different capture occasions were evaluated simultaneously. All six pairs of repeated samples resulted in identical outcomes, verifying the reliability of our method.

Morphological measures were assessed for 60 wild-caught and 29 museum specimens of Pohnpei Micronesian Kingfishers. Male Pohnpei Micronesian Kingfishers appeared to be smaller than females because they were significantly lighter, had shorter wing chords, and there was suggestive evidence that their culmen lengths were shorter (Table 1). We collected complete measurement data for 41 study specimens. Mass data were missing for the 29 museum specimens and 19 wild-caught individuals. The discriminant function resulting from the logistic regression analysis was:

$$
\begin{aligned}
& \ln \left(\frac{\pi_{i}}{1-\pi_{i}}\right)=35.34-0.07\left(\text { wing chord }_{i}\right) \\
& \quad-0.72\left(\text { tarsus }_{i}\right)-0.06\left(\text { culmen }_{i}\right) \\
& \quad-0.19\left(\text { mass }_{i}\right)
\end{aligned}
$$

By including all four morphological characters, the mean response of males and females is significantly different (Type III test; $P=0.02$ ) and negative parameter estimates also verify that males are smaller than females. The discriminant function can also be solved for $\pi$ to yield the probability that a particular individual is a male:

$\pi_{i}=$

$e^{\left(35.34-0.07\left(\text { (ingchord }_{i}\right)-0.72\left(\text { (arsus length }_{i}\right)-0.06\left(\text { culmen length }_{i}\right)-0.19\left(\text { mass }_{i}\right)\right)}$

$1+e^{\left(35.34-0.07\left(\text { (ingchord }_{i}\right)-0.72\left(\text { tarsuslength }_{i}\right)-0.06\left(\text { culmenlength }_{i}\right)-0.19\left(\text { mass }_{i}\right)\right)}$

where morphometric measures for individual $i$ are used, and $\pi_{i}$ is the probability that the bird is male. The discriminant function correctly predicted the sex of $73 \%(30 / 41)$ of the birds from the data set used to derive the equation. Accuracy increased as predicated values approach the extremes of 0 and 1 , which is illustrated by an improvement in accuracy to $86 \%$ (18 of 21$)$ for the sex of individuals with $\pi_{i}<0.30$ and $>0.70$.

\section{DISCUSSION}

Pohnpei Micronesian Kingfishers exhibited reversed size dimorphism, with males smaller than females. Our results revealed that females weighed more than males, and had significantly longer wing chords and culmens. Additionally, the negative parameter estimates and statistical significance of the discriminant function provided further evidence that males were smaller than females. Reverse size dimorphism has also been documented in Laughing Kookaburras (Dacelo novaeguineae; Legge 2000a). Laughing Kookaburras are also in the family Alcedinidae, and their cooperative breeding system is similar to that of Pohnpei Micronesian Kingfishers (Legge 2000b, Kesler 2002), suggesting that similar evolutionary forces may underlie size dimorphism in these birds. Legge (2000a) hypothesized that the size difference may give female kookaburra nestlings an advantage in a species with extreme sibling aggression.

Table 1. Results of $t$-tests comparing morphological measures of male and female Pohnpei Micronesian

\begin{tabular}{|c|c|c|c|c|c|c|}
\hline \multirow[b]{2}{*}{ Metric } & \multicolumn{2}{|c|}{ Sample source } & \multirow[b]{2}{*}{$\mathrm{N}(\mathrm{M} / \mathrm{F})$} & \multicolumn{2}{|c|}{ Mean (SE) } & \multirow[b]{2}{*}{$P$-Value } \\
\hline & $\mathrm{AMNH}$ & Pohnpei & & Male & Female & \\
\hline$\overline{\text { Culmen (mm) }}$ & 28 & 58 & $43 / 43$ & $41.4(0.2)$ & $42.0(0.3)$ & 0.07 \\
\hline Tarsus $(\mathrm{mm})$ & 27 & 45 & $34 / 38$ & $18.2(0.2)$ & $18.5(0.3)$ & 0.20 \\
\hline Wing Chord (mm) & 28 & 57 & $42 / 43$ & $99.1(0.5)$ & $101.0(0.7)$ & $<0.01$ \\
\hline Mass (g) & 0 & 54 & $27 / 27$ & $61.8(0.9)$ & $66.7(1.3)$ & $<0.001$ \\
\hline Total & 29 & 60 & $46 / 46$ & - & - & - \\
\hline
\end{tabular}
Kingfishers from the American Museum of Natural History (AMNH) and Pohnpei, Federated States of Micronesia. 
Despite the statistical differences in mean measures, distributions overlapped substantially for all metrics. This prevented intuitive determinations of sex during fieldwork and necessitated other methods. Single morphological traits can provide useful tools for determining the sex of individuals in other species (e.g., Zavalaga and Paredes 1997), but no individual metric we examined provided a reliable means for sex determination in Pohnpei Micronesian Kingfishers. As a linear combination, however, the four characteristics of culmen and tarsus lengths, wing chord, and mass resulted in a useful discriminant function for sexing birds in the field. The discriminant function's reliability may also be enhanced through additional sampling and the inclusion of alternate morphological metrics.

Despite the utility of the discriminant function, our results indicated that the sex of Pohnpei Micronesian Kingfishers was most reliably determined using molecular genetic techniques. Results confirmed the wide applicability of the primers P2 and P8 described by Griffiths et al. (1998). Furthermore, our modified avian blood DNA extraction protocol provided a simplified and low-cost method for obtaining high-yield and high-quality DNA.

With the simplification of molecular methods and increasing numbers of commercial and research laboratories, molecular sexing is now available to most field researchers for low costs. Blood and feather samples can be sent from study sites using overnight mail, and results can typically be accessed by telephone or internet within two days. Given the importance of accurate sex determination to most research projects, captive breeding programs, and conservation efforts such as translocations and reintroductions, the use of molecular sexing techniques currently seems underutilized.

\section{ACKNOWLEDGMENTS}

We are most indebted to the USGS Forest and Rangeland Ecosystem Science Center and the U.S. Fish and Wildlife Service for financial assistance, and to J. Cracraft and R. Chesser for sponsoring our use of the collection at the American Museum of Natural History. D. Buden, B. Raynor, and S. Derrickson provided valuable technical advice. We also extend thanks to R. Mauricio and landowners on Pohnpei for facilitating fieldwork. M. Boris, C. Cantero, D. Evans, P. Sanzenbacher, J. Santos, and R. Sarsfield provided technical assistance.

\section{LITERATURE CITED}

BAHner, B., A. BALtZ, AND E. Diebold. 1998. Micronesian Kingfisher species survival plan husbandry manual. Zoological Society of Philadelphia, Philadelphia, PA.

Baldwin, S. P., H. C. Oberholser, And L. G. Worley. 1931. Measurements of birds. Cleveland Museum of Natural History, Cleveland, $\mathrm{OH}$.

Buden, D. W. 2000. A comparison of 1983 and 1994 bird surveys of Pohnpei, Federated States of Micronesia. Wilson Bulletin 112: 403-410.

Fry, C. H., AND K. FrY. 1992. Kingfishers, bee-eaters, and rollers. Princeton University Press, Princeton, NJ.

Griffiths, R., M. C. Double, K. Orr, and R. J. G. DAWSON. 1998. A DNA test to sex most birds. Molecular Ecology 7: 1071-1075.

Haig, S. M., AND J. D. BALlou. 1995. Genetic diversity in two avian species formerly endemic to Guam. Auk 112: 445-455.

Jensen, T., F. M. Pernasetti, and B. Durrant. 2003. Conditions for rapid sex determination in 47 avian species by PCR of genomic DNA from blood, shellmembrane, blood vessels, and feathers. Zoo Biology 22: $561-571$.

Jodice, P. G. R., R. B. LANCTOt, V. A. Gill, D. D. Roby, AND S. A. HatCH. 2000. Sexing adult Black-legged Kittiwakes by DNA, behavior, and morphology. Waterbirds 23: 405-415.

Kesler, D. C. 2002. Nest site selection in cooperatively breeding Pohnpei Micronesian Kingfishers (Halcyon cinnamomina reichenbachii): does nest-site abundance limit reproductive opportunities? M.S. thesis, Oregon State University, Corvallis, OR.

, ANDS. M. HAIG. 2004. Thermal characteristics of wild and captive Micronesian Kingfisher nesting habitats. Zoo Biology 23: 301-308. , AND - 2005a. Microclimate and nest site selection in Micronesian Kingfishers. Pacific Science 59:499-508. , AND - 2005b. Selection of arboreal termitaria for nesting by cooperatively breeding Pohnpei Micronesian Kingfishers. Ibis 147: 188-196.

Khatib, H., and Y. Gruenbaum. 1996. Chicken red blood cells as a substrate for direct polymerase chain reaction. Animal Genetics 27: 53-54.

LEGGE, S. 2000a. Siblicide in the cooperatively breeding Laughing Kookaburra (Dacelo novaeguineae). Behavioral Ecology and Sociobiology 48: 293-302.

2000 b. Helper contributions in the cooperatively breeding Laughing Kookaburra: feeding young is no laughing matter. Animal Behaviour 59: 1009-1018.

Pratt, H. D., P. L. Bruner, AND D. G. BerretT. 1987. A field guide to the birds of Hawaii and the tropical Pacific. Princeton University Press, Princeton, NJ.

SAS InSTITUTE. 1999. The SAS System for Windows. Cary, NC.

U.S. FISH AND WiLDLIFE SERVICE. 2004. Draft revised recovery plan for the Sihek or Guam Micronesian Kingfisher (Halcyon cinnamomina cinnamomina). U.S. Fish and Wildlife Service, Portland, OR.

Zavalaga, C. B., and R. Paredes. 1997. Sex determination of adult Humboldt Penguins using morphometric characters. Journal of Field Ornithology 68: $102-112$. 